\title{
ERIC Abstracts to Supplement GRL Reviews
}

In its January issue College \& Research Libraries will inaugurate a new service which should be of considerable use to its readers. In each issue thereafter its "Book Review" columns will be supplemented by abstracts of recent documents of special interest to academic and research libraries.

The abstracts which CRL will print will be selected from those prepared for Research in
Education by the ERIC Clearinghouse for Library and Information Sciences at the University of Minnesota. Unless otherwise noted, documents abstracted in CRL are available by purchase in microfiche or hard copy from the ERIC Document Reproduction Service (National Cash Register Company, 4936 Fairmont Avenue, Bethesda, Maryland 20014). Orders must be placed by "ED" or "LI" number.

\section{Librarians' Association Asks Recognition}

The members of the Librarians' Association at the University of California have submitted a request to University officials for formal recognition of their association. In a letter to University President Charles J. Hitch, the members requested:

1. That the Librarians' Association be recognized by the University of California as the official organization within the University structure which represents librarians as academic personnel.

2. That the University of California grant the Librarians' Association the power to investigate, discuss, and make recommendations to any and all officers and agencies of the University regarding matters of concern to University of California librarians as academic personnel.

3. That the Librarians' Association be granted permission to incorporate the name of the University of California within its own, so that it may become the Librarians' Association of the University of California.

4. That the University of California provide financial support for the activities of the Librarians' Association, including University time for its officers and members to conduct Association business, travel expenses, office space, secretarial assistance, equipment, supplies, etc.

5. That the Librarians' Association be the means by which librarians are represented in an organization including all University of California academic personnel, should such an organization be created; however, that such an organization would not take the place of the Librarians' Association.

\section{NACL REPORT}

The report of the National Advisory Commission on Libraries entitled "Library Services for the Nation's Needs-toward Fulfillment of a National Policy" was submitted to the President on October 3 by Wilbur Cohen, Secretary of the Department of Health, Education, and Welfare, as Chairman of the President's Com. mittee on Libraries. A formal presentation to the President was made by representatives of the Commission at the White House on October 15. The Commission's report appears on pages E9355-9368 of the Congressional Record (Extensions of Remarks), October 21, 1968, vol. 114, no. 173. Copies of the Congressional Record for this date are available from the Superintendent of Documents, GPO, for 20 cents. The report is also available through the ERIC Document Information Service, NCR Company, 4936 Fairmont Avenue, Bethesda, Md. 20014, at $\$ 3.04$ for a hard copy or 50 cents for microfiche (Ed-020-446). A handling charge of 50 cents is added for orders totaling less than $\$ 3.00$, and payment must accompany any order totaling less than $\$ 5.00$. A $25 \%$ service charge is added to orders from outside the United States.

\section{CLS/JCLS MEETING TOPIC}

"Library Instruction Beyond the Orientation Level" will be the topic of the joint College Libraries Section/Junior College Libraries Section meeting at the Atlantic City conference. The presentation will be by a panel of librarians, each giving the description and rationale of his program.

The three people planning the joint meeting -Ruthe Erickson and Betty Duvall of the St. Louis Junior College District, and Evan Farber of Earlham College-feel that in addition to those committed to such instruction, the panel might include someone who takes a negative or skeptical view about the value of such library instruction. They are, however, unable to think of a specific individual.

If anyone is interested in fulfilling this role, or knows of someone else who might be, would he please get in touch with Evan Farber, Librarian, Earlham College, Richmond, Indiana 47374 . 


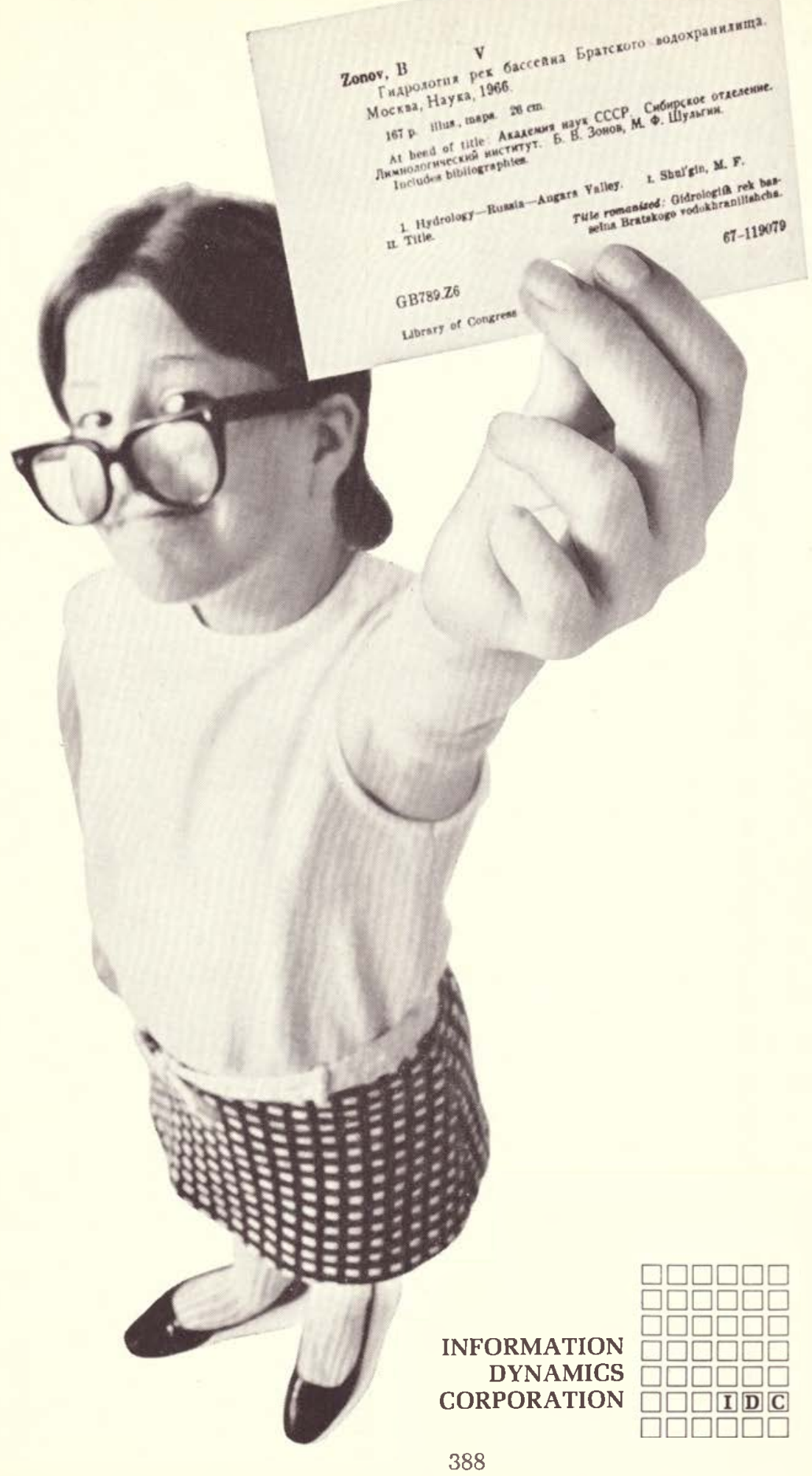


"I found LC 67-119079 in less than two minutes . . . all by myself." That's how easy LC searching is with IDC's Micrographic Catalog Retrieval System. It's the new System that lets libraries use their professional staff to the best possible advantage. And, makes LC search and print out so routine even clerical personnel have no difficulties.

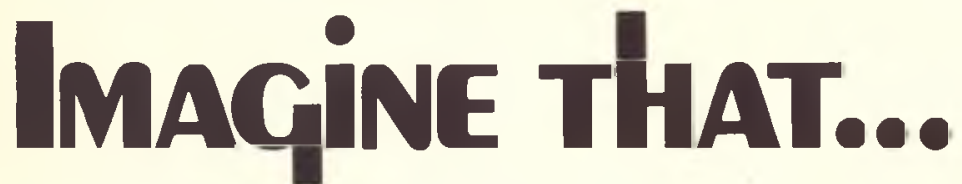

IDC's Micrographic Catalog Retrieval System puts an end to the days when it took a real "pro" to unscramble the Library of Congress Catalog. This new, high speed system automates LC search and print out procedures. To begin with, we've compiled a quickfind Index by both LC Card Number and Main Entry. Then, the actual LC entries are reproduced on Microfiche cards, over 1,100 entries on each card. (A 20-inch desk-top Microfiche file contains millions of entries.) Your people simply locate the entry in the Index, select the proper Microfiche card, and insert this card in a Reader Printer. Six seconds later . . . a full-size LC copy.

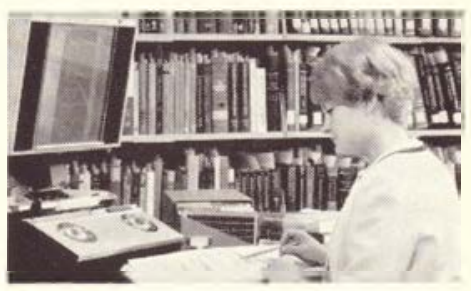

The M-C-R System gives you complete LC searching and print out at a single desk.

IDC's Micrographic Catalog Retrieval System is always up-todate ... weeks ahead of ordering printed LC cards and includes back issues through 1963. Subscribers receive weekly issues on Microfiche of approximately 3,000 advance release LC cards, all alphabetized and interfiled by Main Entry.

Cumulative supplements, issued monthly, quarterly, and annually, are also provided, completely indexed by LC Card Number and Main Entry.

The M-C-R System is the best way to increase the effectiveness of your professional's time, speed work flow, and keep up with current LC output. If you would like us to show you exactly what we mean, simply return this time-saving coupon.

To: Information Dynamics Corporation Library Systems and Services Division

88 Main Street, Reading, Massachusetts 01867

Gentlemen:

HELP! $\square$ Send me more information on the M-C-R System.

$\square$ Have your representative call me for appointment.

I would like a demonstration in my area on

Name

Position

Library

Street

City State Zip 


\section{What book processing centers need is a good $5 \frac{1}{2}$ c book jacket cover.}

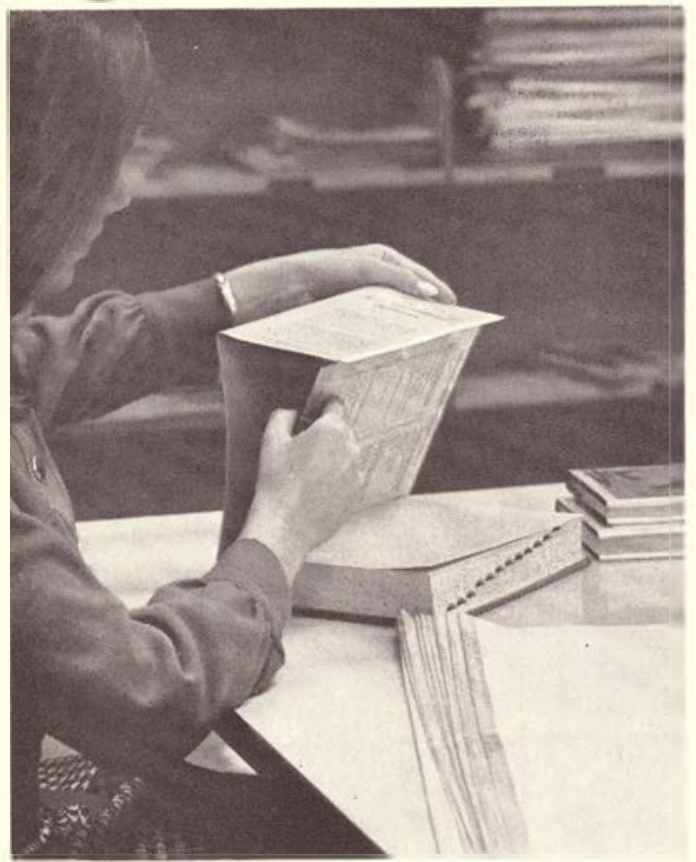

Inexpensive enough to give all books a cover! Low-cost protection for your largest investment. Patron-appeal, because books stay new looking for years.

The new, adjustable $1 \frac{1}{2} \mathrm{Mil}$ Mylar ${ }^{\text {B }}$ Book Jacket Cover costs as little as $5 \frac{1}{2} 4$ per cover, when purchased in quantity by large libraries or book processing centers. Four sizes adjust to most books. Keeps your inventory under control.

Saves processing time, too. No measuring or cutting. Cover slips on in seconds. Then crease to size and tape!

Write on your school or company letterhead for a free descriptive brochure and quantity pricing. 